\title{
Rb-Sr Isochron and K-Ar ages of igneous rocks from the Samnua Depression Zone in Northern Vietnam
}

\author{
Nguyen Minh TRUnG ${ }^{*, * *}$, Nguyen Dieu NuONG ${ }^{*}$ and Tetsumaru ITAYA* \\ *Research Institute of Natural Sciences, 1-1 Ridai-cho, Okayama University of Science, \\ Okayama 700-0005, Japan \\ ${ }^{* *}$ Research Institute of Geology and Mineral Resources, Thanhxuan, Hanoi, Vietnam
}

\begin{abstract}
The Samnua Depresion Zone (SNDZ) extends NW-SE for more than $400 \mathrm{~km}$ from Northern Vietnam to Southwestern China. It represents the northern edge of the Indochina block and is separated from the South China block by the Songma fault. The zone is occupied mainly by Paleozoic sedimentary rocks and Mesozoic volcano-sedimentary successions that are intruded by Mesozoic intrusives and extrusives and by Cenozoic extrusives. Representative igneous rocks of the SNDZ were geochronologically investigated by the $\mathrm{Rb}-\mathrm{Sr}$ whole rock and $\mathrm{K}$-Ar biotite methods. The Rb-Sr ages obtained are $222 \mathrm{Ma}$ for the Nuichua gabbros, $213 \mathrm{Ma}$ for the Songma granitoid (SMG), 203 Ma for the Piabioc granitoid (PBG), 138 Ma for the Banmuong subvolcanic granite, $27 \mathrm{Ma}$ for the Banchieng granitoid (BCG), $218 \mathrm{Ma}$ for the Dongtrau felsic volcanics, $186 \mathrm{Ma}$ for the Muonghinh felsic volcanics and 5.8 Ma for the Cenozoic basaltic rocks (CBR). The K-Ar methods give $252 \mathrm{Ma}$ for the SMG, $237 \mathrm{Ma}$ for the PBG and $24 \mathrm{Ma}$ for the BCG. The groundmass fraction of the CBR yields an age of $1.9 \mathrm{Ma}$. Geochronological comparison and using fossil records suggest that the $\mathrm{Rb}-\mathrm{Sr}$ ages of Mesozoic igneous rocks provide apparent young age, a pseudo isochron age. The major igneous activity of the SNDZ took place during Late Permian-Triassic time to form granitic and felsic volcanic rocks, which were related to the continental volcanic arc magmatism. Minor intraplate igneous activity occurred in the Paleogene. This suggests that the tectonic environment of the SNDZ changed from a convergent plate margin to a matured continental margin in the time span between the Triassic and Paleogene.
\end{abstract}

Keywords: Northern Vietnam, Samnua depression zone, Rb-Sr, K-Ar, Felsic igneous rocks, Basalts

\section{INTRODUCTION}

The structural unit "Samnua" in Northern Vietnam was mentioned first by Fromaget (1941) who called it "Samnua syncline" and described the relationship between it and other structural units such as Songca syncline and Phuhoat massif. In the "Geologic Map of Northern Vietnam", Dovjikov et al., (1965) defined the Samnua structural unit as a depression within the Truongson fold region. Since 1965 , Vietnamese geologists have adopted the same idea in a number of publications on the geology of Vietnam. Tran Van Tri and others (1977) have described the depression events base on the detailed geological studies. However, no geochronological studies have been performed on the igneous rocks that constitute main lithologies in the Samnua Depression Zone (SNDZ) though these studies are so important to understand the details of the Indosinian orogeny.

doi:10.2465/jmps.060628

T. Itaya, itaya@rins.ous.ac.jp Corresponding author
The SNDZ extends NW-SE for over than $400 \mathrm{~km}$ from Northern Vietnam to Southwestern China through Laos (Fig. 1). It represents the northern edge of Indochina block (ICB) and is separated from South China block (SCB) by the Songma fault (Tri et al., 1977; Minh and Hai, 1991; Bao and Luong, 1985; Than et al., 2000; Trung and Itaya, 2002, 2004). It is mainly composed of Paleozoic sedimentary rocks and Mesozoic volcano-sedimentary successions that are intruded by Mesozoic and Cenozoic granitic rocks. Mafic to ultramafic rocks and basaltic extrusives also occur in the zone. The diverse compositions and ages of these igneous activities are not investigated yet except for the Honvan serpentinite body by Trung et al. (2006). In this study, we carried out geochronological studies with the double methods at the Plural Laboratories. Both $\mathrm{Rb}-\mathrm{Sr}$ whole rock isochron ages and $\mathrm{K}$-Ar biotite ages of eight kinds of igneous rocks are presented and two types of ages for each rock type are compared to obtain the reasonable ages for these rocks. The Mesozoic igneous activity in relation to the continental 
volcanic arc magmatism and Cenozoic intraplate igneous activity in the SNDZ will be discussed in the light of obtained isotopic data and geological evidences.

\section{OUTLINE OF GEOLOGY}

The SNDZ is occupied by Paleozoic, Mesozoic, and Cenozoic sedimentary rocks as well as igneous rocks of diverse chemical compositions (Fig. 1). The sedimentary rock sequences are divided into 10 stratigraphic units, Songca Formation_SCF (Ordovician), Huoinhi Formation_HNF (Silurian), Lakhe Formation_LKF (Carboniferous), Bacson Formation_BSF (Carboniferous), Dongtrau Formation_DTF (Middle Triassic), Quylang Formation_QLF (Middle Triassic), Dongdo Formation_ DDF (Late Triassic), Muonghinh Formation_MHF, Khebo Formation_KBF (Miocene) and Quaternary sediment_Q (Pliocene) (Bao and Luong 1985; Minh and Hai, 1991; Bach et al., 1996; Trung and Itaya, 2002). Mesozoic terrigenous formations occupy a large part of the SNDZ. Minor Paleozoic flyshoid sediments and carbonaceous sedimentary formations are distributed along the marginal deep faults (Songma and Songam faults) in the northeastern and the southwestern parts of the SNDZ. The Cenozoic formations occur mainly along the coastal area.
Almost all igneous rocks occur in the northwestern region of the SNDZ (Bao and Luong, 1985; Than et al., 2000; Trung and Itaya, 2002). The main igneous activity took place during the Mesozoic resulting in various types of mafic-ultramafic rocks, granitic rocks, and felsic volcanic rocks. They comprise the Nuichua mafic-ultramafics (NCMUM), Songma granitoid (SMG), Piabioc granitoid (PBG), Banmuong subvolcanic granite (BMSVG), Dongtrau felsic volcanics (DFV) and Muonghinh felsic volcanics (MFV). Banchieng granitoid (BCG) and basaltic rock $(\mathrm{CBR})$ that are not documented also occur in the central and southeastern regions of the SNDZ, respectively.

The Mesozoic sedimentary sequences are closely associated with the Mesozoic felsic volcanic rocks. The latter occurs as a large mass (MFV) in the northwestern region of the SNDZ, suggesting that the mass was a volcanic center for the Mesozoic felsic volcanism.

\section{SAMPLES STUDIED}

The samples to be dated were collected from the granitic rocks of SMG, PBG, BCG, BMSVG, the gabbroic rocks of NCMUM and the volcanic rocks of DFV, MFV and CBR. Sample locations are shown in Figures 1 and 2. Bach et al. (1996) have studied the geology and petrogra-

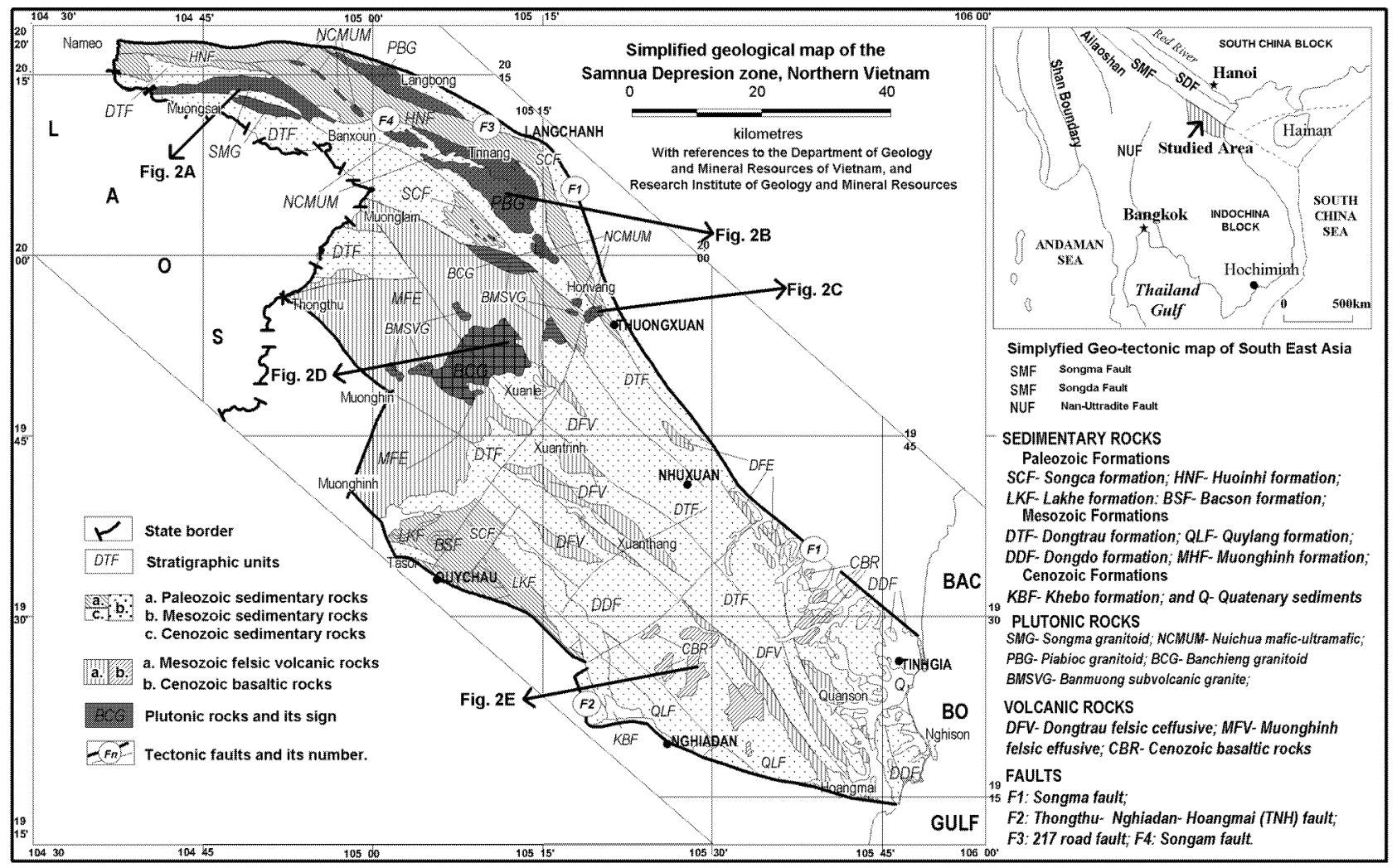

Figure 1. Simplified geological map of the Samnua depression zone in Northern Vietnam. The simplified geotectonic map of Southeast Asia is modified from Metcalfe (2006). 

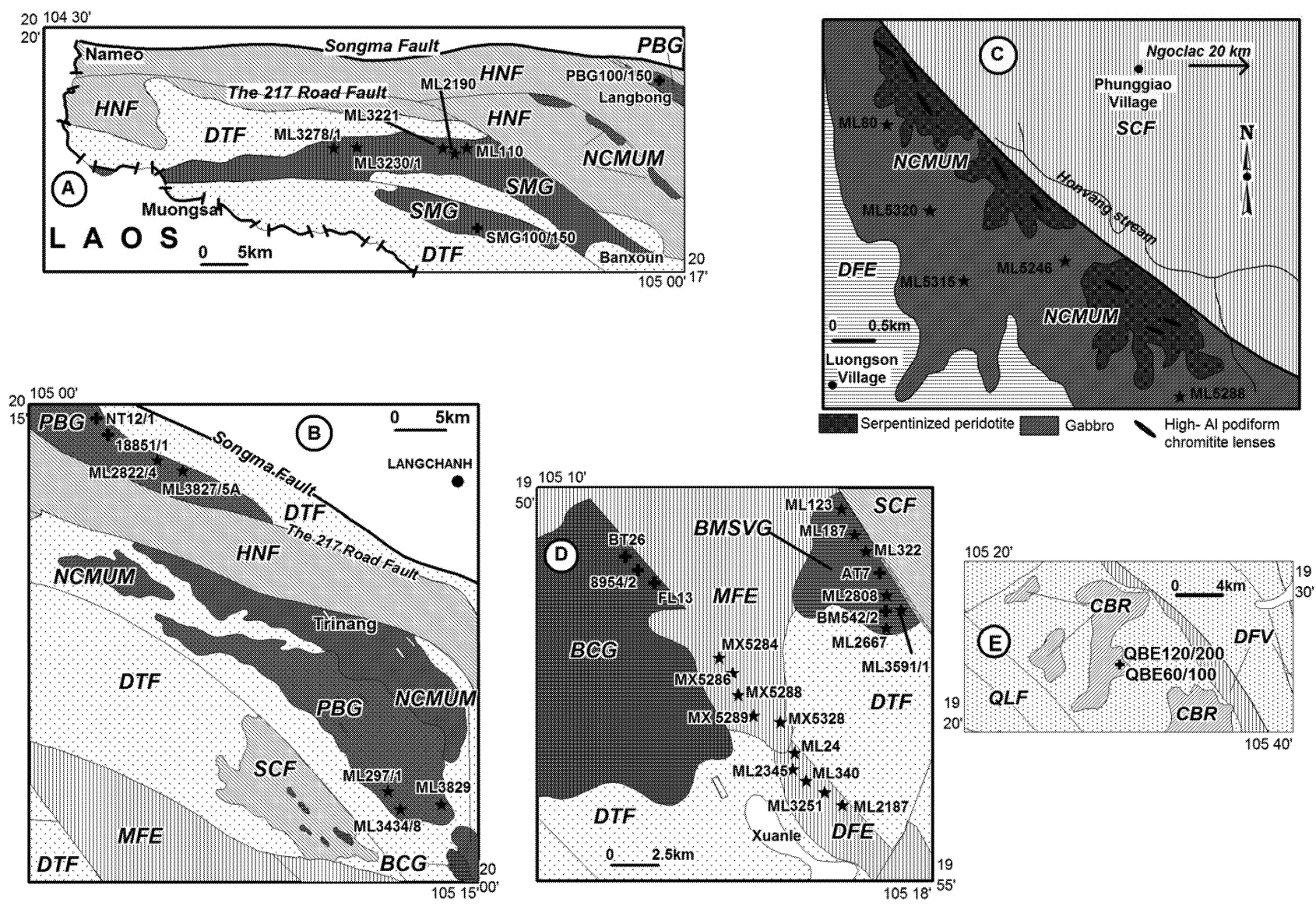

Figure 2. Map showing the locations of the samples analyzed in this study. Legend is the same as that in Figure 1. The symbols, star and cross show locations of the samples analyzed by $\mathrm{Rb}-\mathrm{Sr}$ and $\mathrm{K}-\mathrm{Ar}$ methods, respectively.

phy of these rocks.

SMG cover an area of $65 \mathrm{~km}^{2}$ in the Muongsai area in the northwestern part of the SNDZ. They also occur as small bodies to the south of 217 Road fault. The SMG is composed mainly of hornblende biotite granodiorite and granophyric granite. The granodiorite is a grey to dark grey rock composed of plagioclase $(25-40 \%)$, potassium feldspar (30-45\%), quartz (25-40\%), biotite (5-7\%) and hornblende (1-5\%). Common accessory minerals are zircon, apatite, sphene, epidote, and ore minerals. The granophyric granite is yellowish-gray in color and shows hypidiomorphic granular or granophyric texture. It is composed of plagioclase (25-40\%), potassium feldspar $(30-45 \%)$, quartz $(25-40 \%)$, biotite $(5-7 \%)$ and trace hornblende. Accessory minerals are zircon, apatite and iron ores.

PBG comprises Langbong massif and a series of massifs of different sizes, occurring between the Songma and 217 Road Faults. The main rocks are mediumgrained biotite and two-mica granites that intruded into the HNF and DTF and formed contact aureoles in the formations. The two-mica granite is composed of quartz (30$60 \%)$, potassium feldspar (34-45\%), plagioclase (23-
$25 \%)$, biotite (3-45\%) and muscovite $(0.5-8 \%)$. Accessory minerals are ilmenite, zircon, apatite, tourmaline and magnetite. Concentration of heavy minerals by panning revealed the presence of monazite and fluorite.

BMSVG constitutes the Banmuong, Chiengkhao, Bume and Cuadat subvolcanic formations that are genetically related to the rhyolitic rocks of MFV described below. It is composed of granophyric granite and porphyritic granite dissected by aplite and pegmatite veins. The phenocrysts are potassium feldspar and quartz set in a fine to medium-grained groundmass. The mineral compositions are $35-45 \%$ potassium feldspar (microcline), 15$20 \%$ plagioclase, $28-40 \%$ quartz and $7-15 \%$ biotite. Accessory minerals are apatite, zircon and sphene.

Songchu, Burinh, Bume and Phamay massifs belong to the BCG. The biggest Songchu massif covers an area of $100 \mathrm{~km}^{2}$ at $20 \mathrm{~km}$ west of Baithuong. The massif is zoned and composed of granodiorite, alkali feldspar granite, biotite granite and quartz syenite that have veins of aplite and tourmaline-bearing pegmatite. Alkali feldspar granite and quartz syenite predominate in the massif that intruded the MFV and the BMSVG. Alkali feldspar granite is porphyritic and is composed of phenocrysts of 
potassium feldspar (35-45\%), plagioclase (20-25\%), quartz (20-40\%), biotite (5\%), hornblende (1-2\%) and little muscovite. Accessory minerals are apatite, zircon, topaz, fluorite and tourmaline. Quartz syenite has transitional contact with other rocks, and consists of potassium feldspar (6-80\%), plagioclase (8-30\%), quartz (6-20\%), and little biotite and muscovite. Accessory minerals are apatite, zircon, topaz, fluorite and tourmaline. The vein rocks are very leucocratic and composed mainly of quartz, potassium feldspar, plagioclase and little biotite. Accessory minerals are apatite, zircon, topaz, fluorite and tourmaline.

Trinang gabbroic massif and a series of small-sized gabbro and gabbro-peridotite massifs distributed along Songam fault from Thuongxuan to Nameo belong to NCMUM. The NCMUM comprises fine-grained, massive, weakly laminated gabbro, gabbroic pegmatite, gabbroic diorite, gabbroic diabase, diabase, and some serpen- tinized peridotite bodies. Trinang massif is a lenticular body covering an area of about $45 \mathrm{~km}^{2}$ and is composed of plagioclase (40-42\%), pyroxene (55-56\%) and amphibole (1-2\%). Accessory minerals are apatite, sphene, and ore minerals. Trung et al. (2006) represent the serpentinite body and its related gabbroic rocks as a remnant of paleooceanic lithosphere between the Indochina and South China blocks based on their petrological and geochemical studies.

DFV occurs usually interbedded with DTF marine sediments (Middle Triassic). The DFV-DTF sequence occupies almost all the area of the SNDZ. The DFV/DTF ratio in the sequence is about 0.2 . The DFV is composed of porphyritic rhyolites, quartz-rhyodacite, dacite and light grey felsite. The volcanic rocks include acidic tuffs of up to $10 \mathrm{~m}$ thick. Weakly chloritized biotite and occasionally amphibole are present.

MFV is intruded by BMSVG and unconformably

Table 1. $\mathrm{Rb}$-Sr isotopic data of the igneous rocks in the Samnua depression zone in Northern Vietnam

\begin{tabular}{|c|c|c|c|c|c|c|c|}
\hline Rock & Sample No. & $\mathrm{Rb}(\mathrm{ppm})$ & $\mathrm{Sr}(\mathrm{ppm})$ & ${ }^{87} \mathrm{Sr} /{ }^{86} \mathrm{Sr}$ & ${ }^{87} \mathrm{Rb} /{ }^{86} \mathrm{Sr}(2 \sigma)$ & $\left({ }^{87} \mathrm{Sr} /{ }^{86} \mathrm{Sr}\right)_{\mathrm{i}}$ & Ages (Ma) \\
\hline \multicolumn{8}{|c|}{ Plutonic $\quad$ Rocks } \\
\hline \multirow{5}{*}{ SMG } & ML110 & 140.0195 & 264.8348 & 0.7179 & $2.0615(1)$ & \multirow{5}{*}{0.7121} & \multirow{5}{*}{$213 \pm 10$} \\
\hline & ML2190 & 155.6407 & 225.603 & 0.7204 & $2.6901(1)$ & & \\
\hline & ML3230/1 & 214.8743 & 251.8766 & 0.7221 & $3.3091(1)$ & & \\
\hline & ML3221 & 180.0634 & 113.5616 & 0.7314 & $6.1654(1)$ & & \\
\hline & ML3278/1 & 341.9849 & 81.2453 & 0.7615 & $16.386(1)$ & & \\
\hline \multirow{5}{*}{ PBG } & ML297/1 & 15.183 & 193.0115 & 0.7265 & $0.1792(1)$ & \multirow{5}{*}{0.7259} & \multirow{5}{*}{$203 \pm 5$} \\
\hline & ML3434/8 & 17.8475 & 179.0286 & 0.7267 & $0.2322(1)$ & & \\
\hline & ML3829 & 26.065 & 223.2018 & 0.7268 & $0.2661(1)$ & & \\
\hline & ML2822/4 & 33.9615 & 196.0986 & 0.7269 & $0.3268(1)$ & & \\
\hline & ML3827/5A & 47.6549 & 238.3305 & 0.7272 & $0.4102(1)$ & & \\
\hline \multirow{6}{*}{ BMSVG } & ML187 & 150.5186 & 218.491 & 0.7309 & $2.6827(1)$ & \multirow{6}{*}{0.7257} & \multirow{6}{*}{$138 \pm 5$} \\
\hline & ML2667 & 110.1601 & 149.079 & 0.7316 & $2.8774(1)$ & & \\
\hline & ML2808 & 184.4866 & 197.5735 & 0.7331 & 3.6299 (1) & & \\
\hline & ML123 & 118.9507 & 118.4402 & 0.7335 & $3.9067(1)$ & & \\
\hline & ML3591/1 & 222.4911 & 187.7435 & 0.7348 & $4.841(1)$ & & \\
\hline & ML322 & 312.4447 & 132.9562 & 0.7438 & $9.1343(1)$ & & \\
\hline \multirow{5}{*}{ NCMUM } & ML5315 & 15.7428 & 340.7893 & 0.7067 & 0.0799 (1) & \multirow{5}{*}{0.7065} & \multirow{5}{*}{$222 \pm 10$} \\
\hline & ML5246 & 16.2583 & 243.094 & 0.707 & 0.1903 (1) & & \\
\hline & ML5320 & 6.5803 & 96.2418 & 0.7068 & $0.1114(1)$ & & \\
\hline & ML5288 & 16.2096 & 193.4676 & 0.7067 & $0.0966(1)$ & & \\
\hline & ML80 & 13.7292 & 133.5818 & 0.707 & $0.1815(1)$ & & \\
\hline & & & Volcani & Rocks & & & \\
\hline \multirow{5}{*}{ DFV } & ML2187 & 244.1427 & 129.293 & 0.7238 & $2.256(1)$ & \multirow{5}{*}{0.7151} & \multirow{5}{*}{$218 \pm 10$} \\
\hline & ML24 & 342.7517 & 117.843 & 0.7357 & $6.6042(1)$ & & \\
\hline & ML2345 & 134.2722 & 232.1675 & 0.7346 & $6.1842(1)$ & & \\
\hline & ML340 & 198.3252 & 127.23 & 0.7376 & $7.3375(1)$ & & \\
\hline & ML3251 & 264.7344 & 166.9842 & 0.7502 & $11.3364(1)$ & & \\
\hline \multirow{5}{*}{ MFV } & MX5288 & 218.8672 & 184.1266 & 0.7342 & $4.5734(1)$ & \multirow{5}{*}{0.7227} & \multirow{5}{*}{$186 \pm 5$} \\
\hline & MX5286 & 216.678 & 127.0985 & 0.7411 & $6.6044(1)$ & & \\
\hline & MX5289 & 237.0839 & 134.9514 & 0.7416 & $6.7753(1)$ & & \\
\hline & MX5284 & 258.8811 & 99.5111 & 0.7481 & $10.1202(1)$ & & \\
\hline & MX5328 & 337.1441 & 61.904 & 0.7791 & $21.1865(1)$ & & \\
\hline
\end{tabular}

The analyses were carried out at CGAEV (see text). 

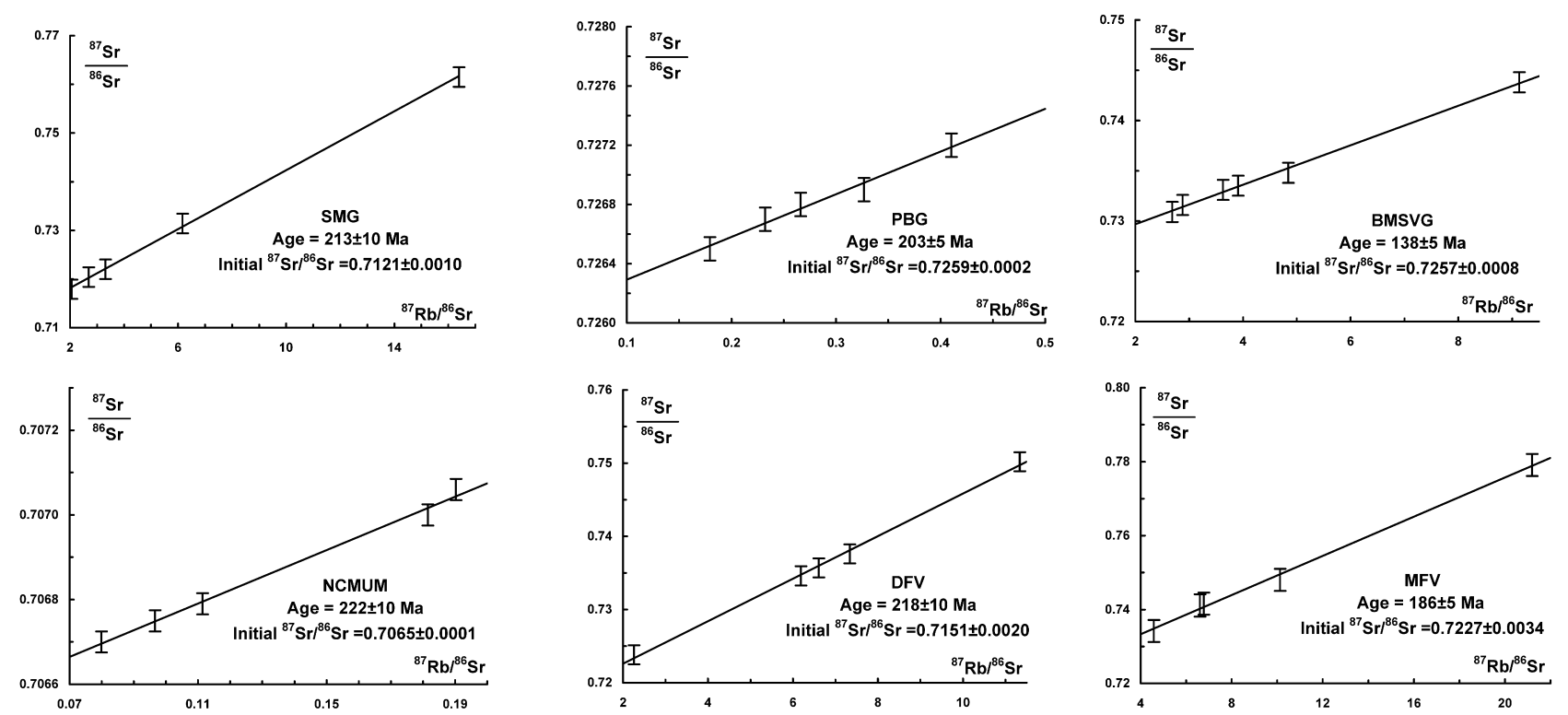

Figure 3. $\mathrm{Rb}-\mathrm{Sr}$ isochron diagram of the igneous rocks from the Samnua depression zone in Northern Vietnam.

Table 2. $\mathrm{K}$-Ar age data of biotites from the igneous rocks in the Samnua depression zone in Northern Vietnam

\begin{tabular}{cccccc}
\hline Rock & Sample No & Analysed sample & Potassium $(w t \%)$ & ${ }^{40} \mathrm{Ar} /{ }^{40} \mathrm{~K}($ atm.ratio $)$ & $\mathrm{K}$ - Ar Age (Ma)(recalculated) \\
\hline PBG & NT12/1 & Biotite & 5.73 & 0.0112 & 192 \\
PBG & NT 2280/4 & Biotite & 6.38 & 0.0106 & 173 \\
PBG & $18851 / 1$ & Biotite & 4.9 & 0.0115 & 187 \\
BMSVG & AT7 & Biotite & 7.08 & 0.0106 & 173 \\
BMSVG & BM542/2 & Biotite & 6.88 & 0.0103 & 168 \\
BCG & BT26 & Biotite & 6.72 & 0.00194 & 33 \\
BCG & $8954 / 2$ & Biotite & 4.66 & 0.0017 & 29 \\
BCG & FL13 & Biotite & 4.32 & 0.0016 & 27 \\
\hline
\end{tabular}

These rocks were dated at VSEGEI (see text).

overlies the rocks aged Triassic. Felsic effusives constitute $80-85 \%$ of MFV by volume, and alternate with conglomerate, sandstone, and siltstone layers in the MHF. In Sopsanh area, MFV occurs as a large mass that comprises massive dacites and rhyolites of greyish blue to pale grey color. Some effusive rhyolites are porphyritic and contain phenocrysts of quartz, $\mathrm{K}$-feldspar, plagioclase and little biotite. Accessory minerals are zircon and magnetite.

CBR is exposed to the north of Nghiadan and Nongcong as a 30 to $50 \mathrm{~m}$ thick flat lava sheet. Dense fresh basalt of ash-grey color occurs in the lower part of the CBR. The upper part consists of porous frothy basalt, which has been weathered in the upper most part into laterite or spongy brown-grey basalt.

\section{GEOCHRONOLOGY LABORATORIES AND THEIR ANALYTICAL METHODS}

$\mathrm{Rb}$ and $\mathrm{Sr}$ elemental and isotope analyses of the rocks were performed with a mass spectrometer VG Sector with nine Faraday cups at the Center for Geological Analysis and Experiment of Vietnam (CGAEV). Rb-Sr isochron age and initial $\mathrm{Sr}$ isotope ratios were calculated by the method of York (1966), using the decay constant of $\lambda^{87} \mathrm{Rb}$ $=1.42 \times 10^{-11} / \mathrm{y}$ (Steiger and Jäger, 1977). K-Ar analyses of minerals were carried out at two laboratories. One is All Russia Geological Research Institute (VSEGEI) of Ministry of Natural Resources of the Russian Federation and another is Research Institute of Natural Sciences (RINS) of Okayama University of Science in Japan. The rock samples were sent to the CGAEV for the $\mathrm{Rb}-\mathrm{Sr}$ analysis and the mineral samples to the VSEGEI for $\mathrm{K}^{-}$ Ar analyses. The $\mathrm{K}-\mathrm{Ar}$ analytical method at RINS has been reported by Nagao et al. (1984) and Itaya et al. (1991, 1996) and then is described below.

The granitic rock samples (SMG, PBG and BCG) were crushed with a jaw crusher and then sieved. Biotites were separated from the $80^{-100}$ or $100-150$ mesh size fractions of the samples. The basaltic rock (CBR) was cut with a diamond saw into thin $(5 \mathrm{~mm})$ slices, to check for freshness and to eliminate coarse-grained phenocrysts and any xenoliths and then ground with an agate mortar. The 60-100 and 100-200 mesh size fractions were separated using fresh nylon-sieve cloth, washed with distilled 
Table 3. $\mathrm{K}$-Ar age data of biotites from the igneous rocks in the Samnua depression zone in Northern Vietnam

\begin{tabular}{lccccccc}
\hline \multirow{2}{*}{ Rock } & $\begin{array}{c}\text { Sample } \\
\text { No }\end{array}$ & $\begin{array}{c}\text { Analysed } \\
\text { material }\end{array}$ & $\begin{array}{c}\text { Size } \\
(\mathrm{mesh})\end{array}$ & Potassium (wt\%) & $\begin{array}{c}\text { Radiogenic }{ }^{40} \mathrm{Ar} \\
(10-8 \mathrm{ccSTP} / \mathrm{g})\end{array}$ & K- Ar age $(\mathrm{Ma})$ & $\begin{array}{c}\text { Non-radiogenic } \\
\text { Ar }(\%)\end{array}$ \\
\hline SMG & SMG100/150 & Biotite & $100-150$ & $2.81 \pm 0.06$ & $2952.9 \pm 28.4$ & $252.6 \pm 5.2$ & 2.6 \\
PBG & PBG100/150 & Biotite & $100-150$ & $6.38 \pm 0.13$ & $6260.9 \pm 59.7$ & $236.6 \pm 4.9$ & 1.4 \\
BCG & TRU04B6-8 & Biotite & $60-80$ & $7.51 \pm 0.15$ & $709.6 \pm 0.9$ & $24.2 \pm 0.6$ & 9.8 \\
BCG & TRU04B8-10 & Biotite & $80-100$ & $7.30 \pm 0.15$ & $817.3 \pm 0.9$ & $24.7 \pm 0.6$ & 13.6 \\
CBR & QBE120/200 & nmf & $120-200$ & $0.65 \pm 0.01$ & $4.8 \pm 0.2$ & $1.88 \pm 0.1$ & 66.9 \\
CBR & QBE60/100 & nmf & $60-100$ & $0.66 \pm 0.01$ & $5.0 \pm 0.2$ & $1.95 \pm 0.1$ & 57.1 \\
\hline
\end{tabular}

These rocks were dated at RINS (see text).

The analyzed material "nmf" of the CBR shows the nonmagnetic fraction from the basalts (see text).

Table 4. Compilation of ages of the igneous rocks from the Samnua depression zone in Northern Vietnam

\begin{tabular}{|c|c|c|c|c|}
\hline & $\mathrm{Rb}-\mathrm{Sr}$ age & $\begin{array}{l}\text { K- Ar age } \\
\text { (VSEGEI) }\end{array}$ & $\begin{array}{c}\text { K- Ar age } \\
\text { (RINS) }\end{array}$ & Fossil age \\
\hline \multicolumn{5}{|c|}{ Plutonic Rocks } \\
\hline SMG & $213 \pm 10$ & & $252.6 \pm 5.2$ & \\
\hline PBG & $203 \pm 5$ & $173-192$ & $236.6 \pm 4.9$ & \\
\hline BMSVG & $138 \pm 5$ & $168-173$ & & \\
\hline $\mathrm{BCG}$ & $27 \pm 1 *$ & $27-33$ & $24.5+0.6$ & \\
\hline NCMUM & $222 \pm 10$ & & & \\
\hline \multicolumn{5}{|c|}{ Volcanic Rocks } \\
\hline$\overline{D F V}$ & $218 \pm 10$ & & & $\begin{array}{c}\text { Anisian } \\
\text { Mollusca } \\
240-233\end{array}$ \\
\hline MFV & $186 \pm 5$ & & & \\
\hline CBR & $5.8 * *$ & & $1.92 \pm 0.1$ & \\
\hline
\end{tabular}

$\mathrm{Rb}-\mathrm{Sr}$ ages of BCG and CBR are after Minh et al. (1991) and Hoang (1996), respectively.

Fossil data are after Bach et al. (1996).

water, and oven dried. Magnetic materials were removed from the fractions using a $\mathrm{Nd}$ hand magnet and then the fractions free of magnetic material were used for the age dating.

Analyses of potassium and argon in the biotite separates and the fraction from basalt, and the calculations of ages and errors were carried out using the method described by Nagao et al. (1984) and Itaya et al. (1991). Potassium was analyzed by Atomic Absorption spectrometry using a $2000 \mathrm{ppm}$ Cs buffer. The method has an analytical error within $2 \%$ at 2-sigma confidence level. Argon was analyzed on a $15 \mathrm{~cm}$ radius sector-type mass spectrometer with a single collector system using an isotopic dilution method and the argon-38 spike (Itaya et al., 1991). Multiple runs of a standard (JG-1 biotite, $91 \mathrm{Ma}$ ) indicate that the error of argon analysis is about $1 \%$ at the 2-sigma confidence level. The decay constants (Steiger and Jäger, 1977) for ${ }^{40} \mathrm{~K}$ to ${ }^{40} \mathrm{Ar}$ and ${ }^{40} \mathrm{Ca}$, and the ${ }^{40} \mathrm{~K}$ content in potassium used in the age calculation are $0.581 \times$ $10^{-10} / \mathrm{y}, 4.962 \times 10^{-10} / \mathrm{y}$, and 0.0001167 , respectively.

\section{AGE RESULTS AND DISCUSSION}

$\mathrm{Rb}-\mathrm{Sr}$ whole rock analytical data are given in Table 1 and their isochron diagram are shown in Figure 3. K-Ar biotite age data analyzed at VSEGEI and RINS are presented in Tables 2 and 3, respectively. Compiled age data for the igneous rocks are shown in Table 4. The $\mathrm{Rb}-\mathrm{Sr}$ whole rock isochron ages give $222 \mathrm{Ma}$ for the NCMUM, 213 Ma for the SMG, 203 Ma for the PBG, 138 Ma for the BMSVG, 27 Ma for the BCG, 218 Ma for the DFV, 186 Ma for the MFV and 5.8 Ma for the CBR. The K-Ar biotite ages obtained in RINS give $252 \mathrm{Ma}$ for the SMG, 237 $\mathrm{Ma}$ for the PBG, and $24 \mathrm{Ma}$ for the BCG. The groundmass fraction of the CBR yields an age of 1.9 Ma. The age data show that the $\mathrm{Rb}-\mathrm{Sr}$ whole rock isochron ages are relatively younger than the $\mathrm{K}-\mathrm{Ar}$ biotite ages (RINS) for the same rock type, except for the $\mathrm{Rb}-\mathrm{Sr}$ whole rock isochron ages of the BCG and CBR, which are older than the corresponding $\mathrm{K}-\mathrm{Ar}$ ages. DFV is interbedded with DTF, which contains Anisian mollusks (Bach et al., 1996), indicating that the sediments were 240-233 Ma old according to the geological time scale by Odin (1994). The geochronological comparison suggests that the $\mathrm{Rb}^{-}$ $\mathrm{Sr}$ whole rock isochron ages of Mesozoic igneous rocks provide apparently younger ages. The BMSVG, in particular, gives a pseudo isochron age (138 Ma) because its $\mathrm{K}^{-}$ Ar biotite ages by VSEGE are 168-173 Ma. Thus, the major igneous activity of the SNDZ took place during Late Permian-Triassic time to form granitic and felsic volcanic rocks.

Trung et al. (2006) found relict chromian spinel having $\mathrm{Cr} /(\mathrm{Cr}+\mathrm{Al})$ atomic ratio $=0.43-0.44$ and olivine inclusions in the Honvang serpentinite body of NCMUM and defined the composition characteristics of the primary minerals in the ultramafic rocks. The inferred original peridotite was lherzolite harzburgite of the type that forms in an environment with a low degree of melt depletion in slow-spreading ocean floor or rift. The gabbro associated with the Honvang serpentinite body has MORB-like geochemical features, suggesting that the Honvang serpentinite body and associated gabbro represent a remnant of 
paleo-oceanic lithosphere between the Indochina and South China blocks. This means that the NCMUM was formed when the paleo-oceanic lithosphere accreted into the northern edge of the Indochina block. The Late Permian-Triassic granitic and felsic volcanic rocks seem to have formed at a typical continental volcanic arc setting, based on the petrographical analyses mentioned above. It follows that the active subduction of the oceanic lithosphere occurred under the northern edge of the Indochina block during the Late Permian-Triassic time. BCG is similar to the rocks derived from a high-potassic magma in northwestern Yunnan and northern Vietnam (Chung et al., 1997; Lan et al., 2000) and is considered to belong to igneous activity within the plate. The typical intraplate alkaline basalts including CBR in the SNDZ erupted in the Pliocene (Hoang, 1996). This suggests that the paleo-ocean between the Indochina and South China blocks had already closed before the $24 \mathrm{Ma}$ old BCG magmatism and that the tectonic environment of the SNDZ changed from a convergent plate margin to a matured continental margin in the time span between the Triassic and Neogene.

\section{ACKNOWLEDGMENTS}

The authors wish to thank all their Vietnamese colleagues for their great help during the period of the study. This research was supported financially in part by the JSPS Ronpaku (Ph.D. Dissertation) program of the first author. They also appreciate the Journal referees whose comments improved the manuscript extensively and $\mathbf{M}$. Santosh for corrections to the final manuscript.

\section{REFERENCES}

Bach, L.D., Quan, D.T., Mong, D.M., Kham, L.D., Chu, N.T., Sang, N.V., Hung, P., Cu, P.N., Thanh, T.P. and Bao, T.V. (1996) Geology and mineral resources of Thanhhoa sheet (E48-IV). Geological Survey of Viet Nam, Hanoi.

Bao, N.X. and Luong T.D. (1985) Geological Map of Viet Nam at 1:500,000 scale, Geological Survey of Viet Nam, Hanoi (in Vietnamese).

Chung, S.L., Lee, T.Y., Lo, C.H., Wang, P.L., Chen, C.Y., Yem, N.T., Hoa, T.H. and Wu, G.Y. (1997) Intraplate extension prior to continental extrusion along the Ailao Shan-Red River shear zone. Geology, 25, 311-314.

Dovjikov, A.E. (editor), My, B.P., Vasilevskaia E.D., Jamoida A.I., Ivanov G.V., Izokh E.P., Huu, L.D., Mareitchev A.I., Chien, N.N., Tri, N.T., Luong, T.D., Quang, P.V. and Long, P.D. (1965) Geology of North Vietnam. Geological Department of Vietnam, Hanoi (in Vietnamese).

Fromaget, J. (1941) L' Indochine Francaise, sa structure geologique, ses roches, ses mines et leur relation possible avec la tectonique. Bulletin du Service Geologique de L' Indochine, XXV1/2, Hanoi (in French).
Hoang, N. (1996) Petrogenisis of Cenozoic Basalts from Viet Nam: implication for the origin of A 'Diffuse igneous province', Ph.D. thesis, University of Illinois at Chicago.

Itaya, T., Nagao, K., Inoue, K., Honjou, Y., Okada, T. and Ogata, A. (1991) Argon isotope analysis by a newly developed mass spectrometric system for $\mathrm{K}-\mathrm{Ar}$ dating. Mineralogical journal, $5,203-221$.

Itaya, T., Doi, M. and Ohira, T. (1996) Very low potassium analysis by flame photometry using ultra low blank chemical line: an application for $\mathrm{K}$-Ar method to ophiolites. Geochemical Journal, 30, 31-39.

Lan, C.Y., Chung, S.L., San, S.J.J., Lo, C.H., Wanga, P.L., Hoa, T.H., Thanh, H.H. and Mertzmand, S.A. (2000) Geochemical and $\mathrm{Sr} \pm \mathrm{Nd}$ isotopic characteristics of granitic rocks from northern Vietnam. Journal of Asian Earth Sciences, 18, 267280.

Metcalfe, I. (2006) Palaeozoic and Mesozoic tectonic evolution and palaeogeography of East Asian crustal fragments: The Korean Peninsula in context. Gondwana Research, 9, 24- 46.

Minh, N.N. and Hai V.N. (1991) Metallogenic Map of Viet Nam. Research Institute of Geology and Mineral Resources, Hanoi (in Vietnamese).

Nagao, K., Nishido, H., Itaya, T. and Ogata, K. (1984) An age determination by $\mathrm{K}-\mathrm{Ar}$ method. Bulletin of Hiruzen Research Institute, Okayama University of Science, 9, 19-38 (in Japanese with English abstract).

Odin, G.S. (1994) Geological time scale (1994). Comptes Rendus de L' Academie des Sciences, Paris, tome 318, serie II, 5971.

Steiger R.H. and Jäger E. (1977) Subcommission on geochronology: convention on the use decay constants in geo and cosmochronology. Earth and Planetary Science Letters, 36, 359362.

Than, L.V., Trung, N.M., Uy, N.D., Hoc, N.V., Thuat, T.D., Manh, L.V., Chinh, K.C., Tuat, L.T. and Ngoc, D. (2000) Tectonics and Metallogeny of North Northern Central of Vietnam. Research Institute of Geology and Mineral Resources, Hanoi, 30-39 (in Vietnamese).

Tri, T.V. (editor), Chien, N.V, Cu, L.V., Hao, D.X., Hung, L., Khuc, D.V., Long, P.D., Ngan, P.K., Quy, H.H., Thanh, T.D., Thi, P.T., Trinh, T., Tan, N., Tung., N.X. and Uy, N.D. (1977) Geology of Vietnam (North part). Geological Survey of Vietnam, Hanoi (in Vietnamese).

Trung, N.M. and Itaya, T. (2002) Brief outline on geology and endogenic mineralization of the Samnua deppression zone in Vietnam. Bulletin of Research Institute of Natural Sciences, Okayama University of Science, 30, 43-51.

Trung, N.M. and Itaya, T. (2004) Podiform chromitites from the Samnua Depression Zone, Northern Vietnam. Bulletin of Research Institute of Natural Sciences, Okayama University of Science, 28, 45-50.

Trung, N.M., Tsujimori, T. and Itaya, T. (2006) Honvang serpentinite body of the Song Ma fault zone, northern Vietnam: a remnant of oceanic lithosphere within the Indochina- South China suture. Gondwana Research, 9, 225-230.

York, D. (1966) Least-squares fitting of a straight line. Canadian Journal of Physics, 44, 1097-1086.

Manuscript received June 28, 2006

Manuscript accepted September 14, 2006

Published online December 27, 2006

Manuscript handled by M. Santosh 